\title{
Study on Management System of Chinese Software Outsourcing
}

\author{
Wengeng Shi \\ iangsu Institute of Trade Technology \\ Nanjing, China \\ e-mail: njswg@sina.com
}

\begin{abstract}
Chinese government is rapidly developing software outsourcing, but the backwardness of the management system has become a major constraint to optimize its industrial structure of the predicament. This article is discussing about provincial software outsourcing from the current level of management system, and from the strategic network perspective on the existing provincial level of outsourcing the management system of the resolution. From the industrial point of view of the way researchers can find the management system reform and strategic path.
\end{abstract}

Keywords- words-software outsourcing; managerial system; comparative study

\section{INTRODUCTION}

The features Software outsourcing industry involves technology, information, software industry, export management, and etc., thus it has relationship with various government departments. Among them, Jiangsu Provincial Bureau of Science and Technology, Information Industry and Foreign Economic and Trade Cooperation are departments implementing national policies or drafting relevant provincial policies for management and support to outsourcing companies by Provincial Government. They also guide the qualification authentication of software companies by Provincial Software Association.

\section{CURRENT FUNCTIONAL ADMINISTRATIVE} DEPART MENTS RELATED TO SOFTWARE OUT SOURCING MANAGEMENT AND THEIR RELATIONSHIP

\section{A. Current Situation of Outsourcing Management System}

Jiangsu Provincial Administration on Intellectual Property Right is mainly in charge of the patent authorization and protection for software outsourcing companies; Jiangsu Provincial Industrial and Business Administration is in charge of the relevant business administration on these companies; Jiangsu Provincial National Tax and Local Tax Bureau are responsible for the carry-out and implementation of tax reduction or refund and related issues in corresponding with relevant national or provincial government department; the Customs is in charge of the supervision and data collection for the exporting of software. Jiangsu Provincial Software Association should be in charge of the internal communication among members and external publicity, besides the work of quality authentication for software companies. The relationship among all major departments is the fair cooperation. [1]

Jiangsu Provincial Bureau of Science and Technology, Information Industry and Foreign Economic and Trade Cooperation are three departments with parallel relationship. They will raise relevant plans and advice separately to Provincial Government for decision-making. Provincial Business Administration, Office of SAT and Office of Local Tax are in charge of relevant policies concerning preference in business and tax. Provincial Administration of IPR is in charge of IPR relevant issues. Provincial Software Association performs its own functions under the business guidance of Provincial Bureau of Information Industry, whereas members in the association are still governed by Jiangsu Provincial Bureau of Science and Technology, Information Industry and Foreign Economic and Trade Cooperation.

The relationship among all major relevant departments is the fair cooperation and coordination. Jiangsu Provincial Bureau of Science and Technology, Information Industry and Foreign Economic and Trade Cooperation constitute major force of software outsourcing management together with the Customs. Bureau of Intellectual Property Rights, Business Administration, Tax and software association also play supporting role in the system and their roles cannot be ignored.

There are still coordination problems of relationships between companies and government, companies and industrial associations, industrial associations and government. In spite that industrial associations are not directly led by the government, they do perform an important function in problems such as acquiring market information for companies, inter-communication, organizing publicities and exhibitions, organizing seminar, rising is sues to the government, and etc. The government should play the role of coordinator between companies and industrial associations and perform a positive and effective function.

\section{B. Stakeholders of Software Outsourcing and their Inter- relationship}

Parties in close relationship with software outsourcing include other stakeholders concerned in the development apart from government departments. They perform different roles from government departments while composing the business eco-system of software outsourcing with government departments together.

Stakeholders concerned in software outsourcing apart from the government include talent suppliers and 
outsourcing investors. Talent suppliers include places nurturing professional software outsourcing talents such as social training institutions, universities, HR agents and etc. They compose the supporting sector of software outsourcing. Post hoc, (1) accelerating the construction of national model software institutes, organizing various training institutions to nurture talents for software industry; (2) positively launching joint-school operation with foreign training institutions, international well-known software companies and domestic software companies, thus to nurture software talents in various models and channels; (3) fastening the introduction of talents, solving the problem of treatment of talents so as to introduce senior talents of software system designing, integrated circuit designing, and software enterprise management to work in Jiangsu; (4) providing convenience for middle and high managements and senior technicians in international communication; (5) encouraging foreign students and other foreign persons to found software outsourcing companies in Jiangsu.

Outsourcing investors and relevant financing institutions are also important sectors for software outsourcing. Post hoc, (1) Gradually establishing and completing property market to realize the capital flow for non-listed software outsourcing companies and to attract investments to software outsourcing from social capitals; (2) Promoting risk-investment mechanism for software industry to encourage risk investment to software industry by broadening channels for the financing of software industry. (3) All software outsourcing companies approved to have the qualification of being listed overseas are allowed to get listed overseas to raise money.

\section{INSUFFICIENCY OF CURRENT SOFTWARE OUTSOURCING MANAGEMENT SYSTEM AND ANALYSIS OF REASONS}

Software outsourcing activity is a business undertaken mainly based on the self-development of companies. Currently the main content of software outsourcing in Jiangsu is software outsourcing, thus the principal body is still software companies. Relevant government departments also play a promoting role in this process. Relevant departments and institutions with software outsourcing are Provincial Bureau of Science and Technology, Bureau of Information Industry, Bureau of Foreign Economic and Trade Cooperation, Bureau of Industry and Business Administration, Office of SAT, Office of Local Tax, Bureau of IPR, and etc. [3]

Relevant parts concerned in software outsourcing apart from the government including talent suppliers and outsourcing investors. Talent suppliers include places nurturing professional software outsourcing talents such as social training institutions, universities, HR agents and etc. They compose the supporting sector of software outsourcing. Jiangsu should accelerate the construction of national model software institutes, enlarge students scale, improve the campus conditions, and enhance the teacher team, courses and textbooks. Universities and Intermediate professional schools should accelerate in nurturing software professionals and programmers. organizing various training institutions to nurture talents for software industry, as well as positively launching joint-school operation with foreign training institutions, international well-known software companies and domestic software companies, thus to nurture software talents in various models and channels. Jiangsu should fasten the introduction of talents, solving the problem of treatment of talents so as to introduce senior talents of software system designing, integrated circuit designing, and software enterprise management to work in Jian.gsu. it should provide convenience for middle and high managements and senior technicians in international communication by simplify ing approval process and lengthen valid period. It should also attract oversea students to come back China as well as encourage foreign students and other foreign persons to found software outsourcing companies in Jiangsu.

Outsourcing investors and relevant financing institutions are also important sectors for software outsourcing. Point to features of software outsourcing, Jiangsu should further bettering software outsourcing management by offering convenient and instant service for software outsourcing by relevant financing institutions. Software export companies in software export bases can open foreign currency account under current account. The income range of this account is foreign currency income under current account, and payment range of this account is foreign currency payment under current account and proved foreign currency payment under capital account. It should support software enterprises that match condition to set up R\&D, marketing and service institutions and offer support in foreign currency.

Through analysis, researchers can see that departments concerning in the software outsourcing enterprises have definite unique responsibilities but have polyisomenis $m$ in some segments. Many software outs ourcing companies are Hi-Tech enterprises and locate in Hi-tech Development Zone and are governed by Bureau of Science and Technology. Meanwhile the Bureau is also in charge of the governing of private science and technology enterprises and relevant intellectual property rights. [4] Software Outsourcing enterprises themselves belong to the software companies and locate in software park, thus Jiangsu Provincial Bureau on Information Industry also govern some relevant parts. The governing particularly shows in the governing of relevant software companies, generates policies for software industry development and protection of IPR of software industry, and accounts for the promotion of external cooperation and guidance of the construction of electronic information industry base and park. Software outsourcing also belongs to the sector of service outsourcing and relates to product export, thus Jiangsu Provincial Bureau of Foreign Economic and Trade Cooperation is also responsible for corresponding parts such as launching relevant policies and regulations of service trade as well as IPR protection in import \& export field. It is responsible for the management of service outsourcing and implementation of national laws and regulation. Jiangsu Provincial Admin is tration of IPR is in charge of issues related to IPR of software outsourcing companies such as IPR negotiation and the application, registration, valuation and filing of patents due to the specialty of products by software outsourcing companies. 


\section{CONCEPTUALIZATION AND STRATEGIC DEVELOPMENT PATH OF SOFTWARE OUTSOURCING MANAGEMENT}

\section{A. Overall Conceptualization of Software Outsourcing Management System}

Software outsourcing system should based on the strategic-ecology taking outsourcing companies as the core so as to promote the competition and cooperation of Chinese and foreign outsourcing companies. Lu Zhen (1994) raised the concept that corporate strategic behavior includes both the plan option by strategic management team of important issues facing by enterprises and the process of solving problems. [5] This essay uses corporate strategic behavior and ecology theories as reference, integrates government functional department and outsourcing enterprises. Chinese outsourcing enterprise is a new-born object with weak vitality. Only to set up strategic ecology network with government functional departments, these enterprises can seek to survive, especially in the early stage of outsourcing companies. [6]

Development Strategy of Software Outsourcing Management System: Establishment of Strategic Allies of Companies, Industrial Association and Government

To develop knowledge outsourcing cannot simply copy only one model. It should form suitable software outsourcing developing models according to specific provincial situation, absorb different experience and involve world software outsourcing market.

\section{B. Knowledge outsourcing strategy path includes following contents:}

\section{a) Market Orientation}

Western enterprises tend to outsource the whole project. Therefore small companies cannot handle it. Indian enterprises have obvious advantages. Companies have more than 10,000 staffers can deliver $1 / 3$ of its people to the US which is almost impossible for Chinese companies. One of the most important experiences enterprises in Jiangsu should learn from India is corporate integration. They should offer total software engineering service ability of software demand analysis, software framework design, software encoding, software testing, project management, and etc. to make enterprises bigger and stronger.

\section{b) Business Options}

Currently, Jiangsu can combine software outsourcing and manufacturing closely to develop plug-in software outs ourcing. For one aspect, plug-in software system is the spirit of manufacturing, thus the development and strength of software outsourcing can provide technique support to the upgrade of manufacturing in Jiangsu to drive the continual increase of manufacturing exporting. On the other hand, the huge opportunities created by manufacturing exporting and out-province demand will in turn further stimulate the sustained development of software outsourcing.

c) Supply Chain Selection

There are following selections for supply chain models: 1 . Cross-province company internal transference; 2. Direct or indirect offer receiving from Japan;
3. Direct offer receiving from western nations; 4. the industry structure model of receiving offers and subcontract. Researchers Researchers should learn Indian model, but Indian model has its serious weak point - lack of self IPR and brand. Researchers should focus more on experience of Ireland and Israel. Software outsourcing in Jiangsu should clarify the position in international division. They should find the sally port, focus on the development of segmental innovative software to form software with own brand and IPR. This is the only way for Jiangsu to take-up the leading position of software producing value chain.

\section{d) Industrial Structure}

Jiangsu should centralize its force to nurture a batch of leading enterprises. It should establish software industry bases, exporting bases, talent bases and innovation bases to nurture and import talents for software industry. It should struggle for $50 \%$ increase in software sales amount annually and $100 \%$ increase in software exporting amount. Meanwhile it should form the network and allies of small companies and outsourcing companies to integrate resources and form certain outsourcing and technique ability.

\section{e) Industrial Support}

Industry supportive model includes two aspects: capital and facility as hardware and technique, information, talent and policy as software. For example, Jiangsu should emphasize and guide the increase of foreign language ability of software talents especially English. It can attempt to carry ways such as teaching software major students professional classes in English or Japanese and increase professional foreign language ability of software staffers relying on agents and professional training institutions.

\section{f) Government Driven Model}

Government should carry strong driven model. As complements, it should encourage building up software outsourcing development allies by many companies based on market demand under coordination of government and industry association. It should enhance cooperation and information sharing, and thus establish strong brand and increase comprehensive competitiveness by resource integration.

\section{REFERENCES}

[1] Gan Weihua, Research on Connotation and Range of Offshore Soft ware Out sourcing Service [J], Business Times, 2010, (33)

[2] Dong Wen, Luo Jing, Governing Features of Software Out sourcing and Strategic Analysis of Software Out sourcing in Xian [J], China Market, 2013, (39).

[3] Jiang Ling, Wen Junwei, Xia Qifeng, Comparative Study on Software Outsourcing Business in China and India [J], China Economist. 2006, (02)

[4] Liu Zhibiao, Service Outsourcing and Strategic Rising of New Economic Forces in China [J], Journal of Nanjing Universityversion of Phylosophy, Human Science and Social Science 2007, 44(4): 4 .

[5] Lu Zhen, Empirical Study on Relationship between .Nondeterminancy of Sense and Corporate Strategic Behavior [J], Journal of Xian Jiaotong University 1994, (6)

[6] Wu Zhenglong, Quality Research of the Relationship between Business Environment of Information Out sourcing Consignees and the Satisfaction and Loyalty of Outsourcing [D]. Shih Hsih University, 2012 。 